Social \& Cultural Geography, Vol. 8, No. 5, October 2007

Routledge

Taylor\& Francis Group

\title{
Madrid's Retiro Park as publicly-private space and the spatial problems of spatial theory
}

\author{
Benjamin Fraser \\ Department of Modern \& Classical Languages \& Literatures, Christopher Newport University, \\ Newport News, VA 23606, USA, benjamin.fraser@cnu.edu \\ The scholarly focus on the production of space necessitates a thorough reassessment of the \\ static categories employed in the analysis of spatial processes. Emphasizing space as a \\ process, this essay calls attention to the recent implication of Madrid's Retiro Park in \\ larger processes of capital accumulation. At the same time, it highlights the insufficiency \\ of the tempting yet problematic distinction between public and private space that obtains \\ in easy solutions to the struggles over city-space. As many critics have pointed out, there is \\ design flaw in the idea of public space-it can never explain how a given space, such as a \\ park, comes to be free of the 'private' (personal and structural) interests operating \\ throughout its societal context. The story of the Retiro ultimately foregrounds the pivotal \\ role of city-space in the drive for capitalist intercity-competition and suggests that the \\ latter process is insufficiently confronted by idealized notions of the role truly 'public' \\ spaces might play in radical democracy and citizenship.
}

Key words: Madrid, Retiro, space, private, public, culture, production.

\section{Introduction}

Those who would give up Essential Liberty to purchase a little Temporary Safety, deserve neither Liberty or Safety. (Benjamin Franklin 1759)

Before all else, the public is the pretext, the cover, for the private needs of each man. (Mariano José de Larra (1975 [1832])

Liberty is a practice. (Michel Foucault 1984)

Madrid's Retiro Park, comparable in many ways to New York's Central Park and situated behind the renowned Prado museum, is a green royal legacy in the center of the city and at the heart of a recent battle over public and private space (Figures 1 and 2 ). ${ }^{1}$ As a space continuously being reshaped by simultaneous material and immaterial forces, the park has recently seen historical restoration, increased privatization, subsequent police intervention and the production of what Steven Flusty terms 'crusty space'-'space that cannot be accessed, due to obstructions such as walls, gates and check points' (1994: 17). At issue is certainly the question 'who has the right to 


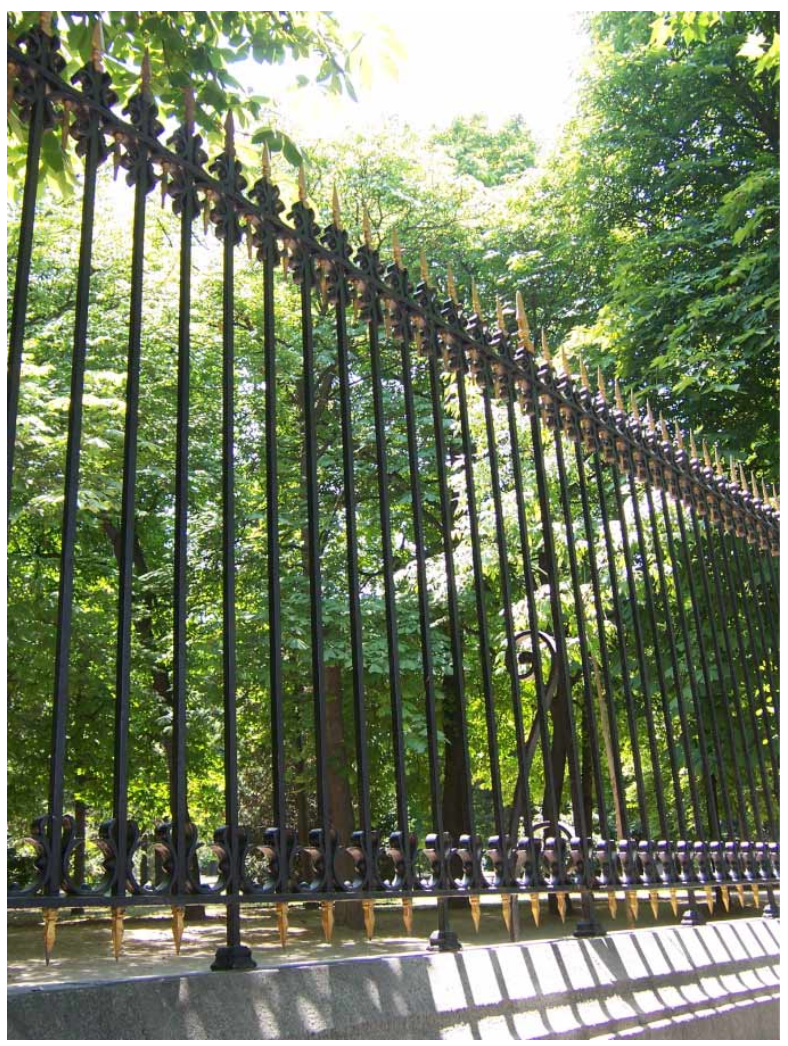

Figure 1 Retiro: outer fence. All photographs taken by the author.

the city?' (Lefebvre 1968: reformulated in Mitchell 2003).

Answering this important question requires exploration of the struggle for power that underlies the cleansing of the park and surrounding areas, whose collective image is being sold to transnational interests and dominated by the intercity competition requisite of a local, regional and national touristcentered economy. It would seem that those with the 'right to the city' are the urban developers who are given priority in shaping city-space and contingent privileges of race and class. How then, to correct this wrong, to assure that the people who live in the city have the right to the park's space as well? I argue here that pursuing this question further necessitates interrogating static concepts of 'culture' and 'public and private space.' It is necessary to show that the struggle over the park is not only a struggle over a space already formed but simultaneously over its contemporary production, a struggle over the conceptual tools and power structures of the here and now.

In this essay I want to call attention not only to the recent implication of Madrid's Retiro Park in processes of capital accumulation, but also to both the materiality and immateriality of culture itself and finally to the problematic distinction made between the so-called 'public' and 'private' spheres of social life. The story of the Retiro ultimately foregrounds the pivotal role of city-space in the drive for 


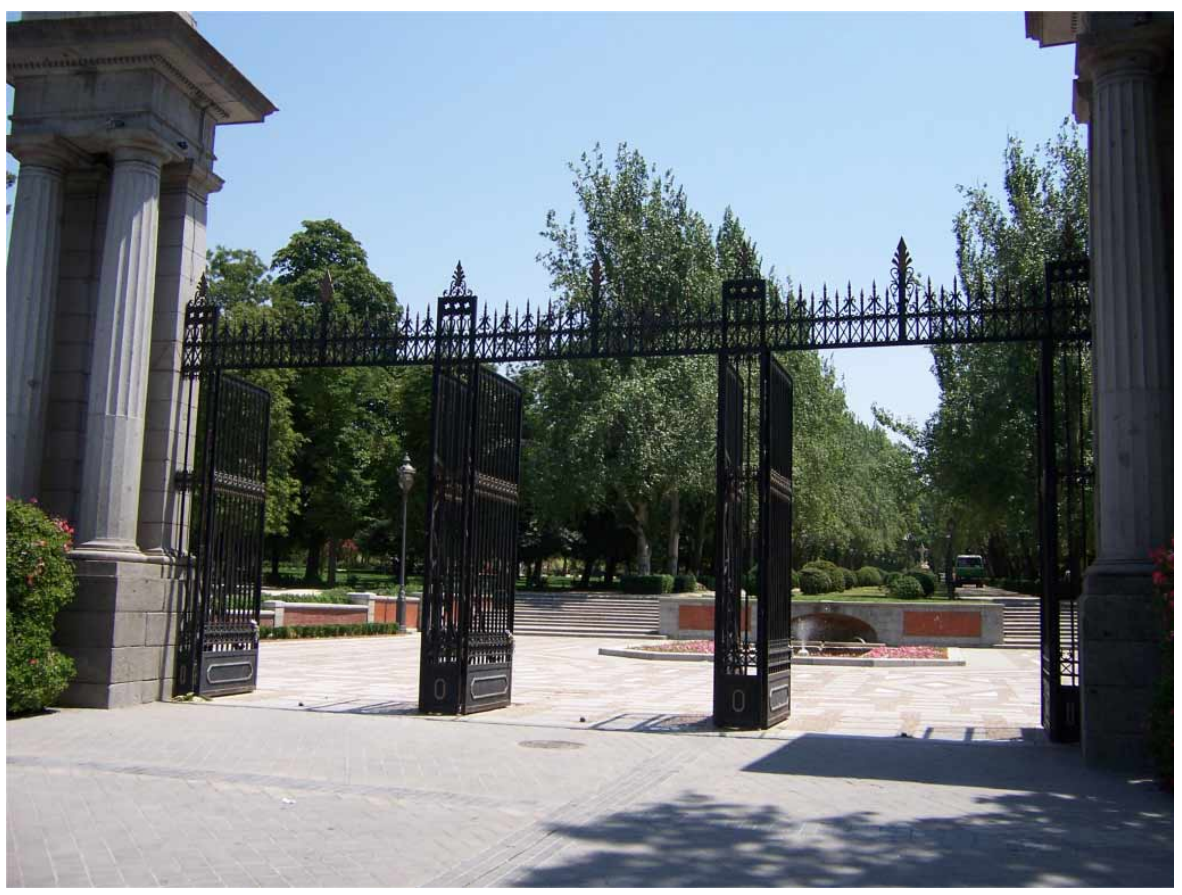

Figure 2 Retiro: Western gate.

capitalist intercity-competition and suggests that the latter process is insufficiently confronted by idealized notions of the role truly 'public' spaces might play in radical democracy and citizenship. As I will argue in the case of the Retiro Park, building radical democracy must not merely seek to overturn the capitalist structuring of private spaces tied to accumulation practices. It is also necessary to acknowledge that unquestioning acceptance of the terms private and public make it possible to wrongly imagine capitalist processes as being either active or inactive, present or absent in a given space rather than running through all spatial and cultural processes as a tendency. Producing a scholarship that is more attuned to the material struggles over cityspace requires that we reject the simplistic solutions proffered by the utopian ideals and tidy categories of much theory. This is the scholarship we must create, even if (and especially because) it means facing the unlikelihood of a quick fix to the vast nature of the problems our cities face today.

First, this essay will seek to establish the public/private distinction as a manifestation of the process of culture. As such, this distinction has produced both material and immaterial effects, and has played a role in not only the production of spaces but the perception and analysis of those spaces. I suggest that we do well in following the lead of scholars who have questioned the public/private distinction and who have also acknowledged the intersection of material and immaterial realities as a key battleground for spatial theory. Next I will briefly explore the insufficiency of the simplistic solutions that become available when the terms 'public' and 'private' are taken to be accurate 
descriptors of a given space. In the sections that follow, I will introduce the reader to the selling of Madrid's Retiro Park-the progressive gentrification of the park through the late twentieth century, the post-dictatorial socialist government's attempt to reclaim Madrid's city-spaces for the people, the subsequent return to speculative interests in the production of space and the resulting heightened privatization and policing of the park in the late 1990s. I will show that these progressive changes to Madrid's Retiro Park and surrounding area during the twentieth century culminated in an operation by the municipal police named 'Turista '98 [Tourist '98].' This operation is best understood in the context of a larger push to 'cleanse' the park's image for sale as part of Madrid's drive to attract capital in a post-dictatorial era of capitalist inter-city competition. I will underscore the degree to which the terms private and public have dominated the discourse on the problems surrounding the park and argue that these terms serve to sever the changes experienced by the park from their larger societal context. I ultimately want to suggest that the battle against the processes that have progressively 'privatized' the park cannot be limited to the park's space itself. Rather this struggle must be connected with a fight over discourse, perception, and the wider acknowledgement that the material and immaterial process of capitalism cannot be counteracted through solely 'material' means. It is important that scholarship recognize that the spatialization of city-space has as its counterpart the spatialization of concepts employed in theory.

I want to make two suggestions before concluding this introduction. First, this argument draws heavily (if indirectly) from Lefebvre's tripartite model of spatial production (1991 [1974]) as well as the tradition of scholarship bent on emphasizing the culturally constructed or negotiated aspect of practices routinely taken to be simply 'natural.' It is the aim of this essay to reconcile these two important traditions of criticism. Understanding space as a process-structured and restructured by produced boundaries and shifting relationships-has as its counterpart the recognition of the produced boundaries and shifting relationships of our intellectual processes. Whereas I cannot hope to do justice to this collective literature in this essay, I hope to provide enough signposts to guide the reader to a few representative works of these traditions. Second, a word of caution is in order regarding the important and yet complex role of the Retiro Park in this essay. This is in no way an attempt to attribute the present-day 'privatized' manifestation of central Madrid's green space to any immutable root cause in the historical sense. Rather, just as the park is a node in the larger city of Madrid, it is a useful starting point in this essay for concerns that exceed the physical space of the park itself. Nevertheless, we do well in noting the historical role of parks in social reform. Roy Rosenzweig's Eight Hours for What We Will: Workers and Leisure in an Industrial City, 1870-1920 (1983) points out that social reformers (in the USA in his example) have long used parks as a key element in confronting urban tensions.

Social control was certainly an important and persistent motivation for many reformers, but to focus exclusively on this aspect of the park and playground movement reduces them to rationally calculating social engineers when actually their motivations were much more complex. Early park reformers, for example, were also sparked by naturalistic visions of society, fears about urban disease, and infatuations with European public gardens as well as by the desire to uplift and quiet the masses. (1983: 127) 
Although it would certainly be interesting to explore the historical evolution of Madrid's central park in more depth here (see Simón Palmer 2001), I wish to take a different direction here rather than suggest that the problems visible in the park are inherent to the park's formation and thus incontrovertible. Moreover, the Retiro Park is indeed one of those same European public gardens to which Rosenzweig alludes in his discussion of the park movement in the USA, and thus predates the concerns he outlines by many centuries. I want to suggest that the concatenated problems of gentrification, tourism, racism and police control over space that are manifest in the Retiro Park today are best understood in the context of contemporary methods of capital accumulation (see Harvey 1990, 1996, 2000). In this context, the struggles over the park's space comprise one possible entry point into larger patterns of injustice that exceed the park itself and run as a tendency through the whole of social life. If the problem of the Retiro is to be solved, scholarship must seek to reconcile the spatialization of the material city with the immaterial and spatialized concepts through which the city is perceived, constructed, analyzed and reproduced.

\section{The public/private distinction as culture}

First and foremost, it is necessary to contextualize the use of the terms 'public' and 'private' within the larger debate over what constitutes culture. Whereas the focus on culture certainly comes from a long anthropological tradition, the word has gained currency in geography in recent years as theorists have begun to move from a more materialist emphasis to an idea of culture as something at once material and immaterial.
When these terms are taken to be actively productive of dynamic spatial practices-and not merely faithful descriptors of static spaces already 'produced'-it is less tempting to seek out simple solutions to the grand problems of city-space. Instead, acknowledging the problems that come with looking at space as either 'private' or 'public' leads to a more thorough understanding of exactly how much has to change in order to create spaces of hope in our cities (see Harvey 2000).

The conception that 'culture' exceeds artifacts is evident in the literature (Lloyd and Thomas 1998; Mitchell 2000; Williams 1977). To be clear: I take 'culture' to be the process through which thought is produced and in turn produces concepts and thus motivates human action. Culture is inseparable from the concepts of race, class, nation, gender, sexuality, language, society and personality/desire. Culture is likewise inseparable from the circulation of capital (Harvey 1990; Mitchell 2000), and yet since Marx, capital is itself a relation (Harvey 2000) and therefore constituted culturally. Sharon Zukin underscores this in her idea of 'culture as an economic base' (1995: 11). As Eric Wolf writes, culture is not merely a 'self-generating and self-propelling mental apparatus of norms and rules for behavior' (1999: 19), although traditional anthropology may have regarded it as such. Rather it is always articulated with power. The term culture, in my analysis, includes this very activity of delineating hierarchies, patterns of subjugation and of privilege. ${ }^{2}$ We are dealing neither with a material world that determines thought nor with a disembodied immaterial thought. Rather, as geographers who emphasize space as process are aware, we are involved in a movement which unites the mental and the physical in the production of space (Harvey 1996; Lefebvre 1991 [1974]; Madanipour 
1996). Most important, however, is 'a notion of the material that admits from the very start the presence and importance of the immaterial' (Latham and McCormack 2004: 703).

The emphasis in cultural geography on bridging material and immaterial aspects of the production of space is not entirely new, and as I have argued (see Fraser 2006) has as its philosophical precursor the work of Henri Bergson. I follow Henri Bergson who in Creative Evolution writes that our very language separates the flux of experience into qualities (adjectives), things (nouns) and actions (verbs) when there is only movement itself (1998 [1907]: 298-304). This is the philosophical starting point for his assertion that the intellect produces categories that take the shape of abstractions overlaid on the physical world, ${ }^{3}$ abstractions that of course subsequently influence the material world itself. Yet, in uncritically accepting these abstractions as the basis of criticism, the real movement of spatial production will always escape, overflowing the immobile sections our mind designs on the flux of experience. This said, it cannot be overemphasized that 'we need to consider more fully how the process of abstraction actually allows us to draw out, and also to become implicated in, the excessive force of materiality' (Latham and McCormack 2004: 707). This idea is crucial to our thinking of spatial practices. I argue that in taking as a starting point such seemingly immobile sections as the division of public and private to faithfully describe the production of space, itself a real movement, we turn a blind eye to the very way in which these categories are produced and reproduced. If, as Bergson would, we assume 'culture' and 'public/private space' to be carved out of the flow of experience, then questions of the subordination of one to the other vanish, leaving questions of power. ${ }^{4}$ We are dealing with what Roy Wagner (1981 [1975]), in a seminal book of anthropology, considers to be The Invention of Culture- a culture that is no less material for having been produced. The challenge for geographers has been to accept that culturally created concepts, such as the distinction between public and private spaces, produce material effects (see also Marston 2000 on scale).

This challenge to geographers and geographical method has been squarely met by a variety of critics whose words on the subject deserve concise exploration here. I follow the more lucid comments of scholars like Mabel Berezin in noting that 'the terms public and private are used with more frequency than with precision' (1999: 358). Ali Madanipour (2003) does well in reminding us of the interdependency of public and private spheres and of the way in which control structures differential negotiation of this boundary. ${ }^{5}$ The opportunity here, when we engage concepts such as public and private space, is to agree with Wahneema Lubiano (1996) that the experience is 'Like being mugged by a metaphor.' Cultural production both engenders material effects and is subsequently transformed by them.

The very idea of a public or private space, then, is an attempt to apprehend through static categories what is better understood as the dynamic movement of the struggle for power. The discussion of the categories of public and private has come a long way since Habermas' (1989) The Structural Transformation of the Public Sphere. Arguments advanced by critics such as Sallie Marston (1990) attempt to loosen the hold these categories have on our thought, while understanding that these categories have measurable effects. Similarly, Rouhani (2001) takes up Lynn Staeheli's (1996) emphasis that public actions take place in spaces thought to be private and that private actions occur in seemingly public 
spaces. Staeheli's work resonates powerfully with the struggle over the Retiro Park at hand and therefore deserves some degree of elaboration here. In separating 'the content of action' from 'the spaces of action' (1996: 601), the critic attempts to combat the constraining effect that labels such as 'private' and 'public' have had when applied to women's political action. This crucial move of scholarship effectively avoids the pitfalls of treating a space as already formed and as having a monolithic and determined meaning or significance. In so doing, Staeheli reinvigorates the possibility of political action while sacrificing none of the importance of a materialist critique of spatial production. As regards the Retiro Park, ultimately I will argue with Staeheli that 'the idea of a unitary space (metaphorical or material) for politics in which individual interests are set aside is impossible' (1996: 617).

Indeed, as Michael Brown (1999) has shown with an intent to reconceptualize 'regime theory', the definition of the public and private spheres is more of a complex act than much scholarship has acknowledged. These are in fact 'multidimensional' (1999: 76) terms whose meanings vary according to the theoretical perspective employed in a given analysis (see also Brown 1997: esp. 123-125; Mitchell 2000: esp. Chap. 8; Staeheli 1996: 603-606). He gives as an explanation that whereas Lockean Liberalism separates the state (public) from the market (private), the Romantic conception of the split identifies both state and market as public and the community as private, and Critical Feminists oppose both state and market (public) to the domestic sphere (private) (Brown 1999: 75-76). Matt Houlbrook's Queer London further emphasizes the shifting nature of the public/private boundary, emphasizing the 'interplay between public and private' (2005:
54) and suggesting that 'public and private sociability [have] often overlapped within the same venue' (2005: 75). I would like to agree with Brown's assertion that 'radical democracy transgresses public-private binaries (whatever their axis)' (1997: 124) and further underscore that, to a large degree, this necessity of radical democracy is rooted in the need to counteract the role capitalism plays in partitioning and producing spaces. Noted scholar of space, Henri Lefebvre, has written extensively on this characteristic tendency of capitalism and I would like to briefly attend to the foundations of his work before moving on to discuss the Retiro Park itself.

Perhaps the most lucid comment of Lefebvre's, and the one that best represents the whole of his work, is his dictum that capitalism has survived through the twentieth century 'by producing space, by occupying a space' (The Survival of Capitalism, 1973: 21). The tripartite model of spatial production contained in Henri Lefebvre's The Production of Space (1991 [1974]), a watershed in the current of contemporary spatial analysis, highlights the multidimensionality of spacein this model, spatial practices, representations of space and spaces of representation all collectively engender the real movement of spatial processes (1991 [1974]: 33). ${ }^{6}$ Space is held to be not merely physical but mental as well. Through this model Lefebvre emphasizes the relational nature of what we otherwise take to be the static ground for our activity. Lefebvre's model of space as a relation not only stresses the importance of our ideas and conceptions of space in 'the production of space'-taken in the historical sense of spaces already produced by capitalism-but also makes possible and even necessary the questioning of the spatializing tendencies of our perception, interpretation and analysis of spatial practices. Just as the notions of private 
and public have played various roles in the production of city space up to this point, their unquestioned use in theory and practice will continue to influence current practices of spatial production. I argue that questioning these terms does not lead to an exercise in abstraction but rather results in a return to the materially-immaterial world in which mental oppositions and physical relations of force are deeply entwined. In this way, the influence of capitalism is unmasked to reveal not only relations of power conceived in purely material terms, but also our own complicity in seeing the world through terms that structurally reinforce the disparities of capitalism's own uneven development through cityspace. If we are to fully embrace Lefebvre's suggestion that we conceive of space as at once physical and mental, we must not only attune ourselves to the expression of immaterial categories in material spaces, but simultaneously to the spatialized categories active in the mental processes of perception, analysis and criticism.

\section{Private space: solutions to the problem, problems of the solution}

In this section, I want to explore the pernicious nature of the opposition between 'public' and 'private' and how it subtly and frequently rears its head in even the most progressive critiques of the use of city-space. At the same time I want to stress that this distinction is more geared towards resolving issues of access to space in the short term and as such does relatively little to combat the underlying structural cause of marginalization. Questioning the hold that these terms have on scholarly discourse will lead to a more thorough (if initially disheartening) understanding of exactly how much needs to change in our cities if we are to create a more just society. Ultimately, the struggles taking place in our cities are not merely over access to a given place. Rather, whether it be Hyde Park in London, the Retiro Park in Madrid, or a key node in any other city, a given place is, to put it simply, a starting point for a complete reevaluation of the spatial practices and spatialized thinking processes that run throughout society as a variegated whole. Spatial practices, as Lefebvre was aware (and as Bergson arguably intuited before him) are at once mental and material, and are intimately bound up with the whole of social life. There are thus two widely divergent focal points that may be adopted by those seeking to combat the 'privatization' of a 'public' space. The first, which emphasizes who is prohibited access to the park, leads to a fight for inclusion. The second, which questions that people are prohibited access to the park, leads to a more apt critique of the process of exclusion itself.

D. Mitchell's The Right to the City (2003) is a well-constructed example of the first approach. ${ }^{7}$ His analysis focuses on the homeless and their access to space often using parks as privileged moments in the space of the city as a reference point for the marginalization of this group. His argument is important, coherent, and avoids reifying spatial practice, allowing that the right to inhabit space can only exist as an activity and thus that people must actively claim space as their own through strugglepublic space is 'always only proven in practice, never, that is, guaranteed in the abstract' (2003: 4). Nevertheless, this approach does little to critique the very structures that allow for exclusion ${ }^{8}$ nor the false ontological assertion that 'public' space may exist. Though it is tempting to believe otherwise, there can be no space bereft of 'private' ideas as long as humans move through it or even imagine it from afar. What is 'won' through struggle is 
never an area cleansed of all marginalizing discourse but rather an area with both visible and invisible, actual and virtual configurations for movement through that space. Rather, if a given struggle is successful, the area is reproduced with a specific idea resulting from said struggle in mind. ${ }^{9}$ The question then is not simply a matter of which actors are involved, but one of a discourse that marginalizes. It is deceptively simple to argue that to combat the restrictions over access to a park, struggle must necessarily be framed in terms of the park's being made public. It may be true in practice that 'To the colonialist offensive against the veil, the colonized opposes the cult of the veil. ${ }^{10}$ Yet the battle over the use of a citypark, like the cult of the veil, must always be turned toward the larger ideas of public and private spheres, toward the idea of colonizing stigmatization and capitalist accumulation strategies. The fight over the veil that Fanon mentions is not merely over a veil, and the struggle in the Retiro is not only over a park. Thusly, the solution to limited access to city space indeed lies in the active claiming of the park for the power struggle, but also in the unmasking of the public/private distinction as a socially-constructed though productive thought-exercise that must not be uncritically accepted as categories in analysis.

The first focus I have outlined above-who has access to the park-does well in reminding us of the meaning of active struggle in shaping space, yet is limited in that inclusion for one group of people or another leaves mechanisms of exclusion intact. It can give us only a partial picture of spatial practice. It fails because it does not sufficiently grapple with the problematic mental cartographies of public and private space involved in the process of exclusion. It fails because the seemingly contradictory nature of the idea that a culturally produced category may produce real effects is not sufficiently integrated into its critique. Let us see how this contradiction operates. Though Mitchell questions that public space ever 'simply existed,' he employs only a slightly less muddled reification of the concept upon asserting that it indeed is 'socially produced through struggle' (2003: 8). His emphasis on process, while beneficial, has opted not to question the category of public/private space itself. Both Mitchell and Giroux (2001) have argued that the public is not unproblematic. Mitchell (2003: 130-134) brings out Marston's critique that the public is inherently exclusionary (and in my estimation, thus not 'public' at all). His argument is driven towards the inclusion of the homeless into a space that he believes can be made truly public through action. In a similar fashion, Giroux writes that:

It is not that a genuine democratic public space once existed in some ideal form and has now been corrupted by the values of the market, but that these democratic public spheres, even in limited forms, seem no longer to be animating concepts for making visible the contradiction and tension between what Jacques Derrida refers to as the reality of existing democracy and 'the promise of a democracy to come'. (2001: 30)

While he admits that a genuine public space has never existed, Giroux falls into the trap of arguing that a public 'sphere' should exist in limited ways, rather than questioning the very possibility of there ever being a true distinction of 'public/private.' At the same time that it has suggested the inadequacy of the concept, scholarship has been, on the whole, reluctant to dispense with the idea of public space completely. This seeming contradiction must be explicitly addressed. If, as I am arguing, the public is merely a sphere (or a space) in which private needs are realized and thus not a 
worthy mental category, then the critic of spatial practice has the responsibility to analyze how those private needs are necessarily realized in the public through a power struggle-i.e. (as Lloyd 1997 shows for example) always at the expense of other needs. This is not power in the sense of distribution of resources or talks of rights or of inclusion of the homeless, as Mitchell stresses, but rather power in the Foucauldian sense of discipline and in the larger-scale sense of stateeffects. Mitchell is right to echo Lefebvre in his questioning 'who has the right to the city.' Yet while fighting for inclusion of a certain group of marginalized can at least temporarily solve material problems of living in the city for a given group at a given time-in Mitchell's case the homeless-such activity will not change the processes which construct the very issue of exclusion itself. What is needed is a criticism that relentlessly questions the distinction of the public/private as a way of tackling much more subtly pervasive interplays of power, and an action that although mobilizing itself in a given space, refuses to be quelled by modifications to that place only. Criticism and action need to synchronize to a movement in which the particular is always articulated in coordination with the universal. Struggles over space are necessarily and simultaneously over ideas that overflow their expression in any given place.

In 1832, Spain's most acerbic and disgruntled Romantic critic and essayist Mariano José de Larra argued that, 'Before all else, the public is the pretext, the cover, for the private needs of each man' (1975 [1832]) (compare with Staeheli 1996, above). This invective, launched against what Larra saw as a reprehensible nineteenth-century Spanish society, bodes ill for Hannah Arendt's philosophically-meditated and somewhat idealistic Enlightenment-era notion of the public.
Although the idea of a public sphere detached from the private realm has been sufficiently critiqued by many (see Rouhani 2001; Young 1990), Marston (1990) has most convincingly shown how the public is built on exclusions. Likewise, Marshall Berman (1986) demonstrates the use of public squares in assuring adherence to doctrine through violent means, documenting the Plaza Mayor of Madrid's role in the horrific auto-da-fe ceremonies of Inquisitorial Spain. Such exclusions and violent enactments of constructed normality are by nature anathema to the idea of the public sphere of equality in speech and action promoted by Arendt and outlined below. A fundamental acknowledgement that 'public' space is always exclusionary should work towards questioning the very distinction of 'public/private' space, yet often criticism is unable to fully resist its siren's call. ${ }^{11}$

\section{Selling city-space: the Retiro}

As many critics have argued, the landscapes of the city are no mere backdrop to social action, but rather are part of the production of the social struggles (Zukin 1991) and contradictions of modernity (Berman 1982). They are a created moment with further constitutive force (Mitchell 2000), 'fashioned from a natural landscape by a culture group' (Sauer 1925: 343), and 'an activity' (Wilson 1991: 102) or a relationship between people and place. As such a landscape, the Retiro has moreover become part of the selling of place for tourist consumption in a competitive global market (see Logan and Molotch 1987; Madanipour 2003; Philo and Kearns 1993; Thorns 2002). Chris Philo and Gerry Kearns, in Selling Places. The City as Cultural Capital Past and Present) (1993, describe three ways in which history is used to 'sell place.' 
The first occurs when local authorities and local entrepreneurs self-consciously draw upon the economic and social history of a particular place as a source of pride and inspiration for the present ... The second and related possibility here entails the use of 'heroic' imagery surrounding historical processes as a lever for money-making and persuasion in the present ... The third possibility here involves the planned adoption of all manner of historical references, particularly architectural references, in the fabric of the built environment, so as to foster the 'cosy' ambience of a place that is basically familiar. (1993: 6)

As recent urban projects have sought to sell Madrid in the realm of interurban competition, they have used all three of these methods. In the following section, we will see how the park and surrounding areas have become part of efforts to restore Madrid's patrimony, to seek out the false shadow of historical accuracy, and also to police cityspace in order to preserve the tourist-image of place. These decisions more than ever focus on attracting tourism and business investment instead of on a real effort to produce social justice. For example, Compitello documents how the governance shift from the Partido Socialista Obrero Español (PSOE) [Socialist Spanish Worker's Party] to the conservative Partido Popular (PP) [Popular Party] in 1996 precipitated a turn to 'urban boosterism and selling place' (2003b: 405). In this context, Madrid's Retiro Park is in no way an isolated case, but rather represents a turn away from nineteenth-century recreational uses of parks for respite and escape towards a twentiethand twenty-first-century model that values city space as important for capitalist accumulation. ${ }^{12}$

Capitalism thereby builds and rebuilds a geography in its own image. It constructs a distinctive geographical landscape, a produced space of transport and communications, of infrastructures and territorial organizations, that facilitates capital accumulation during one phase of its history only to have to be torn down and reconfigured to make way for further accumulation at a later stage. (Harvey 2000: 54)

These processes must necessarily intensify in the city that necessarily engages in interurban competition. As capital becomes urbanized it is also globalized, and the idea of selling place in a global economy becomes a city's main focus (Harvey 1996). To be sold, places must undergo a minimization of difference. ${ }^{13}$

That the changes in and around the Retiro from 1990 on have been driven by a notion of homogeneity/'coziness' is not surprising given that 1990 was the 'European Year of Tourism' (see Owen 1992). In order for tourism to succeed class conflict must be erased from the landscape and minority-groups removed or policed (Zukin 1995: 25), written out of that place's history. Parks, as privileged moments in the process of 'how cities use culture as an economic base' (Zukin 1995), thus become key nodes in the accumulation of capital, transnational and otherwise. Attempting to homogenize space is not an easy task. De Certeau (1984) insists that spaces exist only through the movements that form them. If migrants 'in a way subvert, or make holes in existing urban plans,' if 'they develop their own "tactical" ways of walking and conversing within those plans and creating their own pathways by, so to say, manipulating the plan' (Diken 1998: 83), this must be a movement which legitimately produces, and inherently diversifies, space. And if, as Ali Madanipour (2001) convincingly argues, space has 'multiple meanings,' inter-city competition necessitates the suppression of those meanings which inhibit the accumulation of capital. In order to 


\section{Benjamin Fraser}

produce homogenized space, then, the distinction between private and public space becomes a key weapon.

\section{The Retiro and surrounding areas}

The Retiro Park began its days under the Catholic King and Queen's rule (Montoliú Camps 2002: 672). 'The preferred place of royalty since the age of Felipe II, it was Felipe IV who pushed for its creation and in 1868 it was handed over to the township., ${ }^{14}$ Although control of the park has since passed from the ruling class of a nineteenth-century, and still feudal Spain, ${ }^{15}$ to the ruling class of a late twentieth- to early twenty-first-century capitalist Spain, it is quite evident that the park remains tied to the mode of production that envelops it. The Park is located within and shares its name with Madrid's third district. The Retiro district is located with the boundaries established by the Plaza de Cibeles, the paseo del Prado, the plaza del Emperador Carlos V, the avenida de la Ciudad de Barcelona, the calle de Antonio Nebrija, the borde Norte de las vías del Ferrocarril dirección Sur, the avenida de la Paz, the calle de O'Donnell, the plaza de la Independencia, and the calle de Alcalá ending back at the plaza de Cibeles (Gea Ortigas 2002: 17). This 350-acre green space comprises, among other things, a lake with rowboats, the ruins of the San Isidoro de Avila church, the Crystal Palace (Figures 3 and 4), the botanical gardens, many sculptures, monuments, fountains and walking paths, and has seen the establishment of the royal porcelain factory (established by Carlos III; Figure 5), the Astronomical Observatory

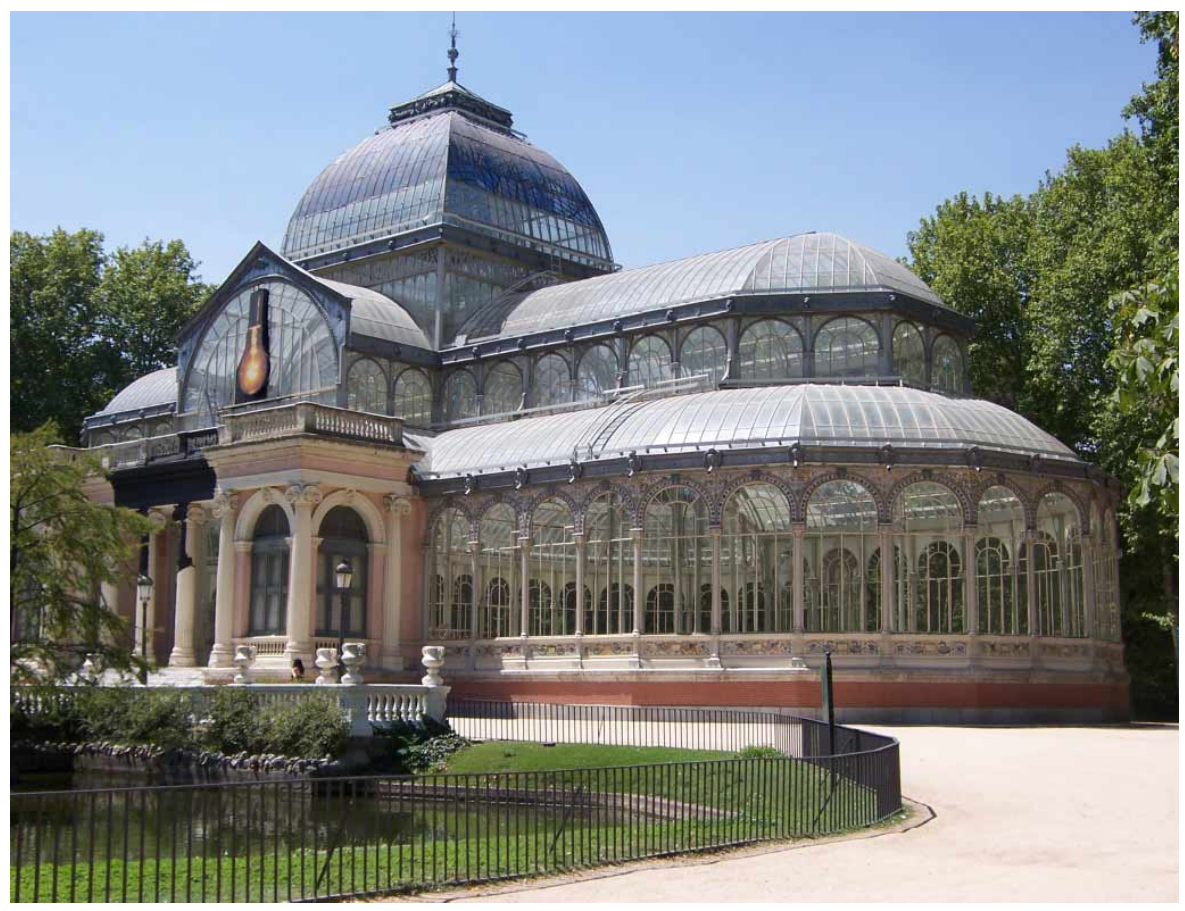

Figure 3 The Palacio de Cristal. 


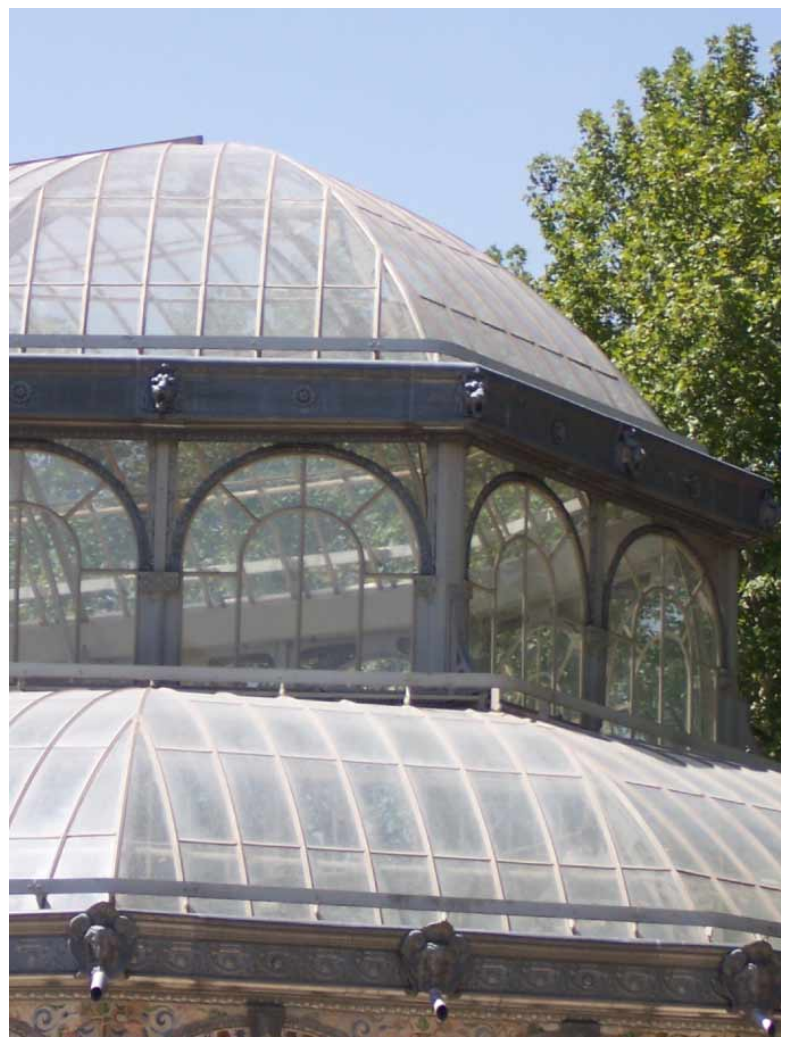

Figure 4 The Palacio de Cristal, detail.

(Carlos IV), and the Central Meteorological Institute (1892). Not surprisingly, the park is located in an area of Madrid that now bears the familiar signs of gentrification (Vidal Domínguez 1988), the production of a space geared toward the attraction of international business and tourist capital.

As Edward Baker and Malcolm Alan Compitello so cogently argue in the prologue to their edited volume Madrid de Fortunata a la M-40: Un siglo de cultura urbana (2003), after the Spanish Civil War (1936-1939) that left Madrid in ruins, the Franco government was faced with the task of planning the development of urban living spaces to house the flux of immigrants fleeing the poverty of country life (2003: 22). Nevertheless, the authors correctly characterize the response during the dictatorship (1939-1975) as a period in which abuses of power were complicit with the private sector. After the dictatorship, the Constitution of 1978 transferred the responsibility of urban planning to the autonomous communities of Spain (Baker and Compitello 2003: 24), yet it was not until the socialist victory in municipal (1979) and national elections (1982) and the resulting Plan General Urbano of 1985 that a real attempt was made to use urban planning as a tool for the good of the people. ${ }^{16}$ The first objective of the Plan is illuminating in this regard: 'Luchar contra la segregación social de la ciudad ... confirmando el carácter popular de los barrios [To fight against the social 


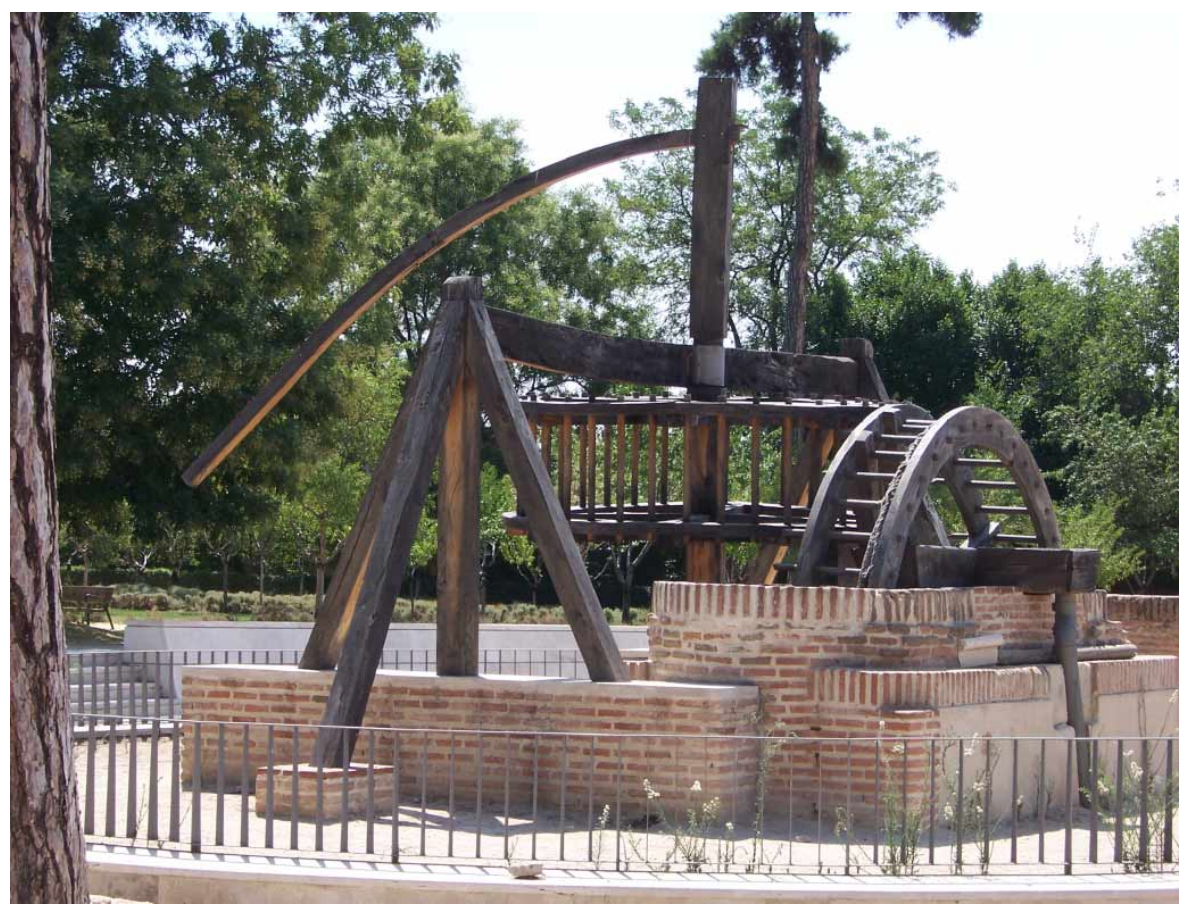

Figure 5 Remains of the Fábrica de Porcelana.

segregation of the city ... confirming the popular character of its neighborhoods]' (Baker and Compitello 2003: 24). This attempt to reclaim city-space for the people sought to reverse the patterns of housing that had obtained in the late years of the dictatorship.

At the beginning of the twentieth century, housing in older sections of the zone known as El Retiro was originally directed to workingclass peoples, yet, the middle class soon occupied these dwellings. In the 1960s and 1970s, the same pattern emerged nearby. The zone known as Niño Jesús was first directed to middle-class professionals, but was occupied by the more accommodated middle class who installed pools and gardens among other renovations characteristic of their class privilege. Housing in Estrella was constructed for lower/middle-class families but was soon occupied by middle-class professionals. Fuente del Berro, too, underwent a change from lower/middle-class to solidly middle-class residents. In all cases the pattern emerges in which the underclass is pushed to the outer rim of the city or from one place to another as cities try to secure a safe haven for transnational, local and regional capital. Produced homogeneity displaces the real wealth disparities created by practices of flexible accumulation that now globally dominate the construction of space. Conceived as a correction to exactly this speculative use of the city's built environment, the fourth objective of the Plan General underscores the mounting need to 'Frenar la tercerización del Centro y su utilización para edificar viviendas cada vez de mayor lujo [To stop the gentrification of the Center and its use 
to build housing of ever-greater luxury]' (Baker and Compitello 2003: 24)

Ultimately, however, the speculative practices of capitalism that were already taking hold in Spain during the late-years of the dictatorship continued through the 1980s and 1990s in Madrid. ${ }^{17}$ In the case of the Retiro Park and surrounding areas we see these practices affecting a production of space tying into (1) the Retiro metro stop, (2) processes of historical preservation in the park itself, (3) the parallel development of 'crusty space' in the park and (4) an increased policing of the park.

The Retiro metro stop (Figure 6), declared a Monumento Histórico Nacional [National Historic Monument] in 1997, has been remodeled in an attempt to sell Madrid's urban space.
The kiosks and locales that were installed without respect for the station's aesthetic will be relocated to square with the original idea. In old photos held by the Train Museum one can appreciate that the pharmacy, the deli, the confectioner's shop all maintained the station's intrinsic style. ${ }^{18}$ (Commisso 2000)

Here, as elsewhere, historic preservation serves as an attraction for urban explorers, tourists on the quest for authenticity. The connection between authenticity and consumption can rationalize any shaping of space. Today, historic preservation is also very much alive inside the park itself. Most recently, a massive campaign to restore historical monuments has been underway in the Retiro. Restorations have been performed on over 182 statues, 174 sculpture groups,

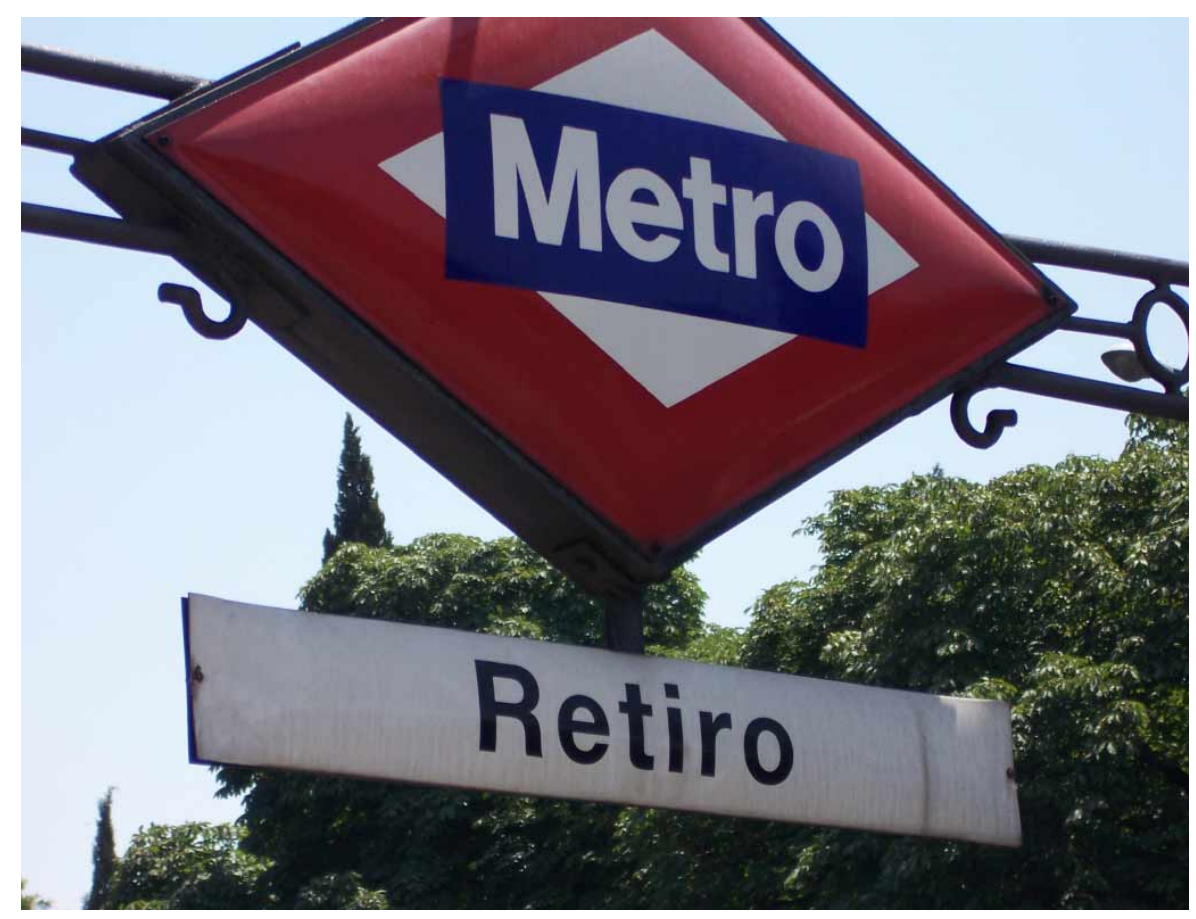

Figure 6 The Retiro Metro stop. 


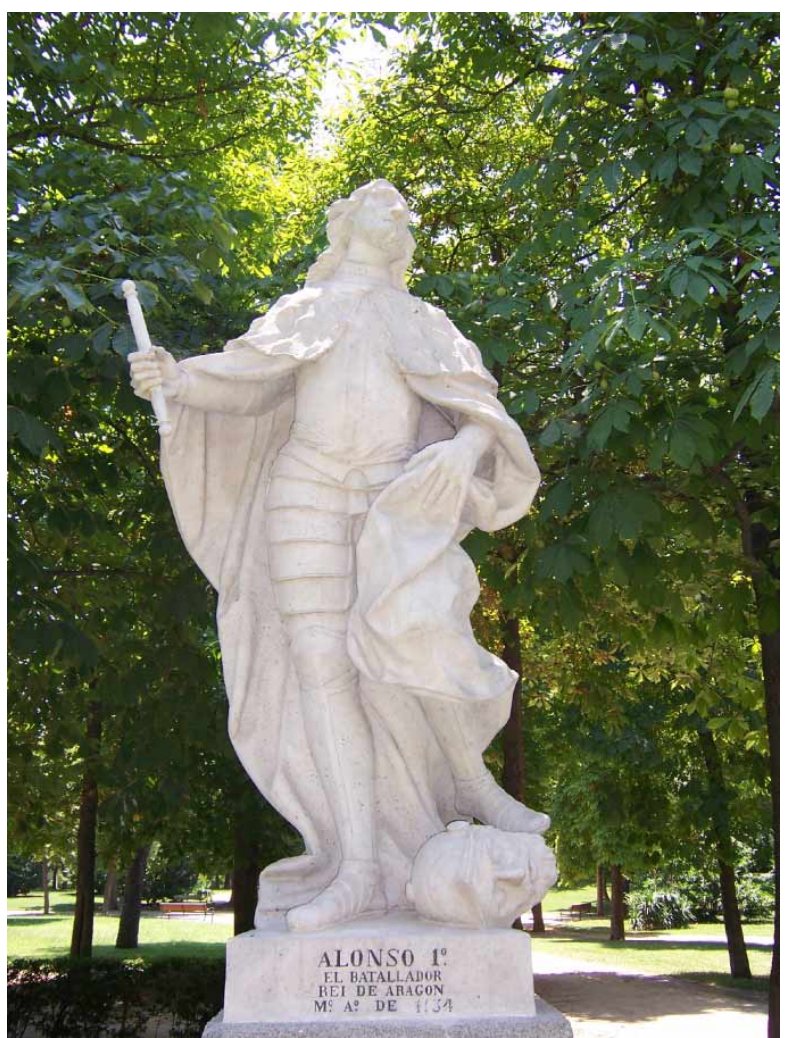

Figure 7 Statue of Alonso I.

397 fountains, and 17 doors and arcs (Esteban 2001) (Figures 7-10). Slated for restorations, even the top of the statue of Alfonso XII at the water's edge has been closed to the public since 1990 (El Mundo, 16 March 2000). Documentation of the cleanup has even been organized into a museum exposition itself, as Sigfrido Herráez, member of the Concejal de Vivienda y Rehabilitación Urbana [Council of Urban Housing and Rehabilitation] explains, because 'Madrileñans do not have sufficient knowledge of the monumental patrimony available to them, ${ }^{19}$ (Esteban 2001). As regards the production of space it seems there is always a need to document, and in this case, to document in a museum the documentation that already exists in the park, itself a museum.

These changes to the space in and around the Retiro Park have been contemporaneous with the production of what Flusty has termed 'crusty space'-'space that cannot be accessed, due to obstructions such as walls, gates and check points' (1994: 17). In the 1980s, the park was closed to all but foot traffic (Simón Palmer 2001: 141). The 1990s saw the increasing privatization of the park's supposedly public space. Initially, an attempt to close the park at the start of the 1990s did not fully succeed due to the lack of perimetral barriers. Yet, in 1995, the park's closing, facilitated by new fencing, was announced 'for 

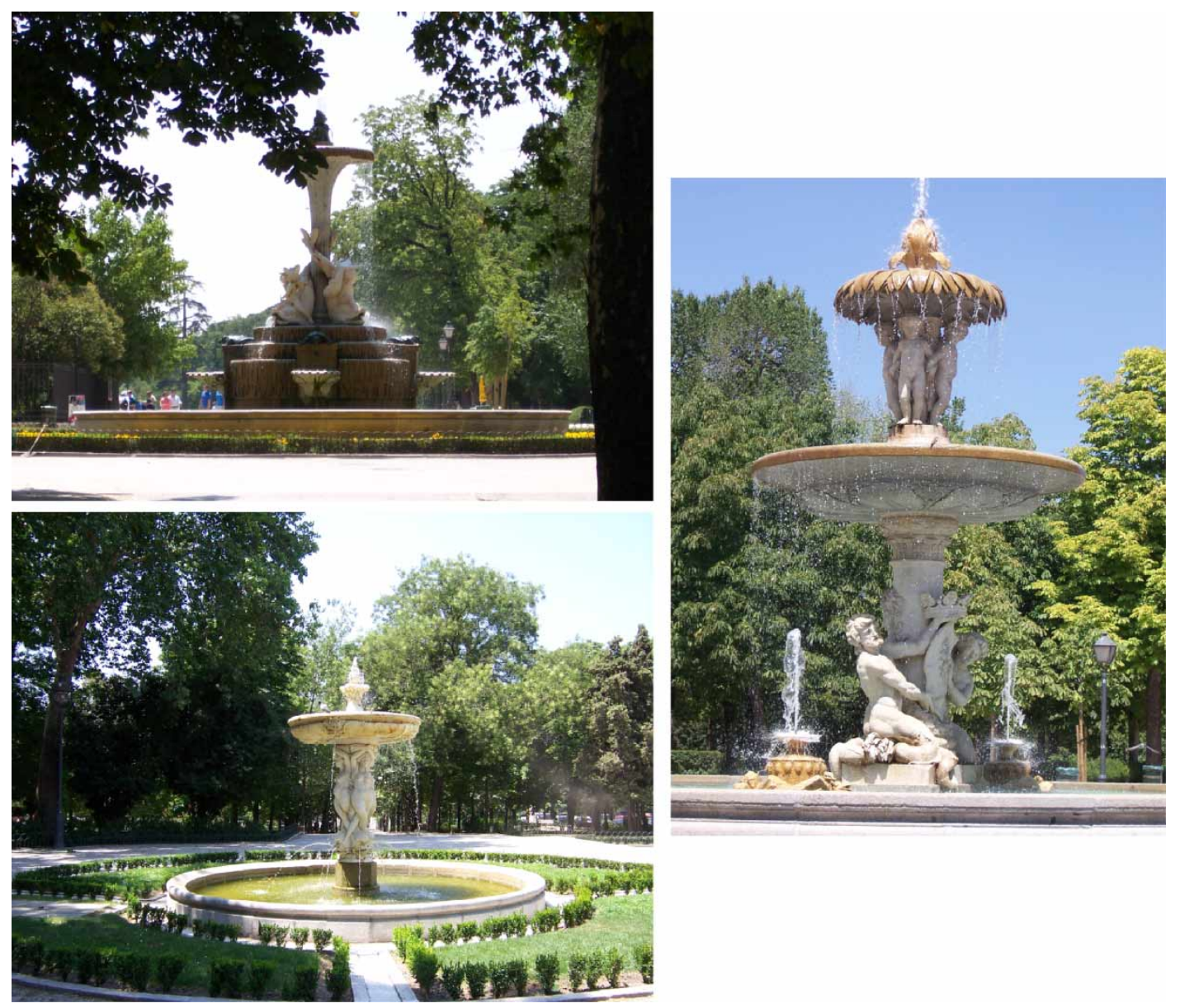

Figures 8-10 Fountains of the Retiro.

reasons of security and in order to avoid vandalism, $^{20}$ (Blasco 2000). Yet the police response $^{21}$ to this call for security was largely aimed towards cleansing the park of racial difference. Non-governmental organizations such as SOS Racismo have denounced the increased policing of the park. Rosa Tristan (1998a) describes the presence: 'Police on horseback, in cars, on motorcycles. Dozens of agents scour the park of the Retiro every day for hours in search of the immigrant. ${ }^{22}$ Pedestrians of African or Arab appearance are routinely and systematically stopped and asked to produce papers (Tristan 1998a). Even if the papers are in order, they are told to leave. During June and July 1998, she continues, the municipal police identified 990 people as suspicious. Of these, 911 had no result whatsoever. The operation, part of the aptly named 'Turista '98 [Tourist '98]' found:

16 seizures of small quantities of drugs, one knife; one undocumented person; three people cited for consuming a type of narcotic in public and 56 minor interventions that include anything from walking a 
dog without a leash to a lost child or a traffic fine for circling the park. ${ }^{23}$ (Tristan 1998 b)

That the name of the immigrant hunt was 'Tourist '98' should not be taken lightly, nor should the fact that illegal activity was underrepresented among those labeled suspicious.The gentrification, historic preservation, production of crusty space and increased policing both in and around the Retiro Park are the varied results of a single ideal-the desire to sell Madrid, and the Retiro area as a key attraction of the latter (Figure 11).

Protests against the privatization of public space have found a symbolic home in the theatrical monumentality of the Retiro Park itself. The monument to Alfonso XII at the water's edge in the center of the park has been the site of many pro-immigrant protests, important given the anti-immigrant stance of the park's policing (Figures 12-14). On 23 July 2000, for example, various immigrant rights and human rights groups assembled by the monument to protest the offensive 1985 Ley de Extranjería [Foreigner's Law]. Under this law, in the words of the organization Papeles para Todos [Papers for All], 'the immigrants that arrive to Spain will not be persons with legal recognition and rights, but rather "illegals obligated to accept any given job condition, to stay out of sight, to remain quiet in the face of injustice" ${ }^{24}$ (El Mundo, 24 July 2000). Given the increased policing of the park, it was the perfect site from which to launch a protest against the mistreatment of immigrants in the city. The rhetoric of privatization is everywhere, deeply entrenched in the struggles over space. And yet, even among protestors quite validated in their fear of a growing neoliberal presence in the

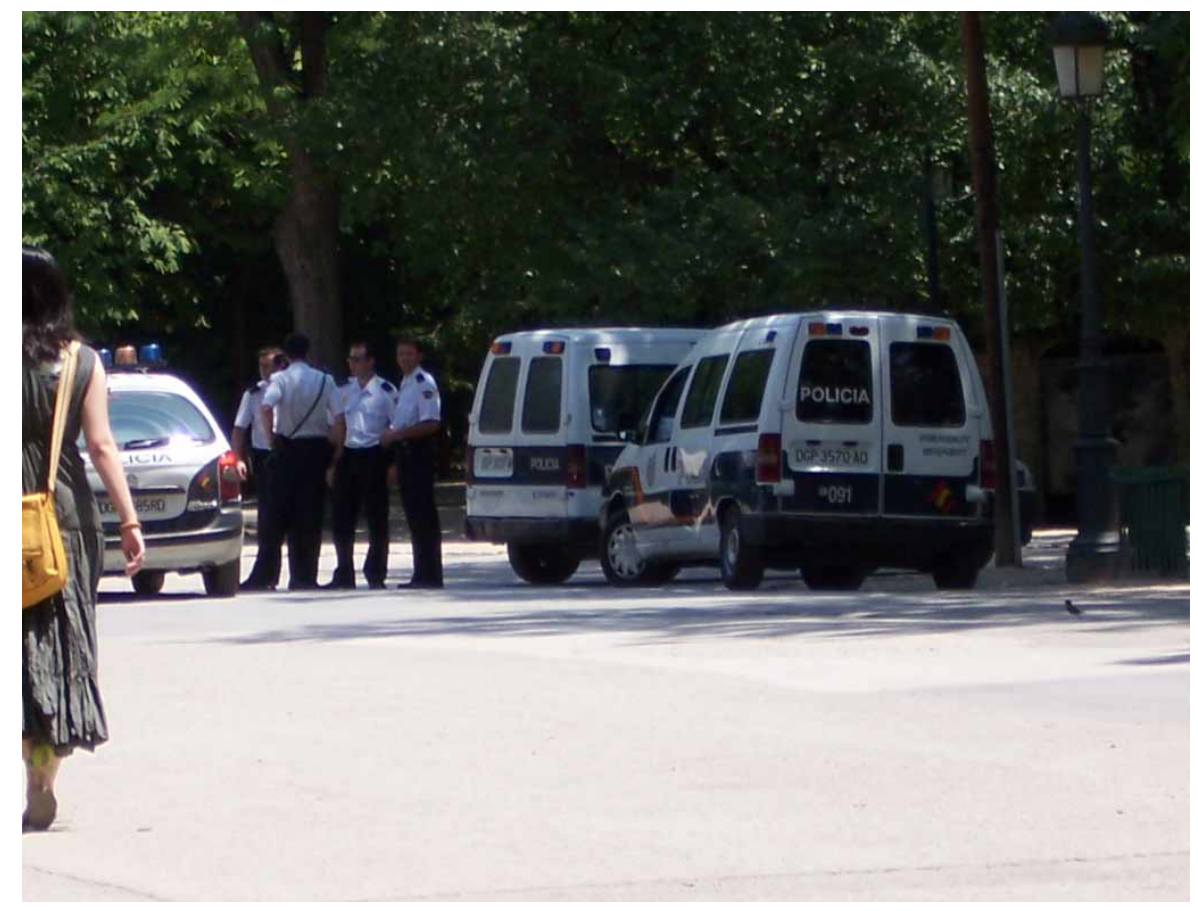

Figure 11 Police presence north of the Estanque. 

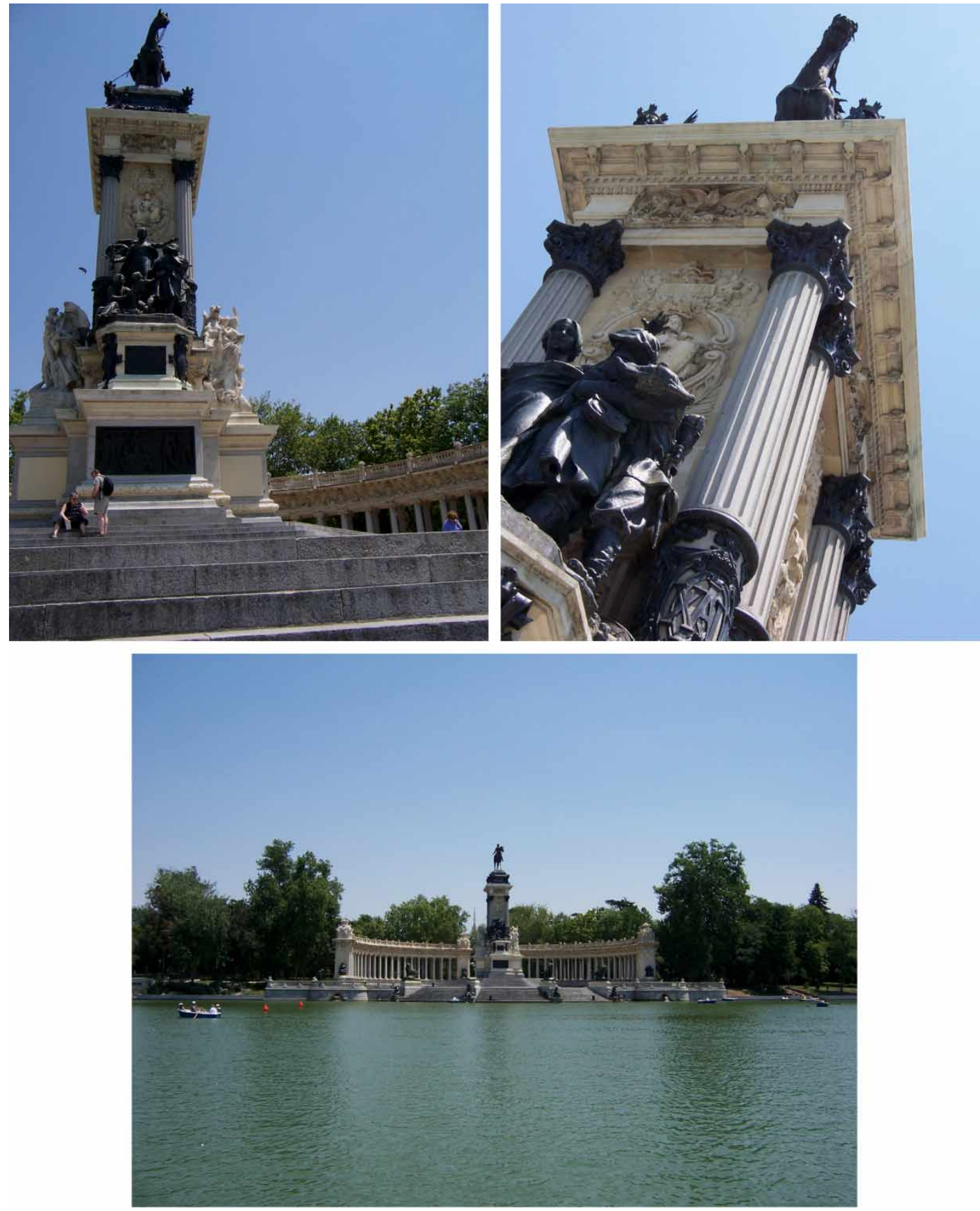

Figures 12-14 Statue of Alfonso XII and the Estanque. 
university, public utilities, the political economy or a park in Madrid, 'public' space is a concept that simplifies how space is produced.

Now, it is easy to argue, as has Berman (1986) drawing on Marx's 'The Jewish question' (1844), that the bourgeois revolutions of the nineteenth century split the human being into a private person and a public person and, consequently, that 'A society of split men and women badly needs a terrain on which people can come together to heal their inner wounds-or at least to treat them-and advance from political to human emancipation' (Berman 1986: 476-477). The traditional idea of public space rests on this very distinction between the public and the private, with the simultaneous privileging of the former over the latter. Arendt (1958) perhaps best displays this point of view, arguing that people must be able to come together in public in a 'space of appearance. ${ }^{25}$ Within this approach, the public is an ideological realm of possibility. The 'space of appearance' is not any physical space, i.e. it is not the Retiro Park, yet the Retiro Park is a possible locus for the public, which is an act that must be reactivated continually. The problematic nature of this assertion comes to view in that the 'public' entails, for Arendt and for other critics of her tradition, that one must sacrifice some 'private' part of the self upon entering the 'public' sphere (see Canovan 1985; Passerin d'Entreves 1992). It is easy to see how Mitchell (2003) has followed this line of thinking (see also Habermas 1989). And yet the ontological status of the conceptual barrier public/private is questionable (see Fraser 1989). To accept the distinction is to downplay the pervasiveness of a hierarchical model of behavior and power relations in favor of provisional and pernicious mental categories. That entering the public requires the suspension of the private is true only for those without the power to enforce their interests. To accept the very idea of public and private is thus a position that takes for granted an underlying deployment of power that is displaced by the use of these categories. In 1743, Fernando VI allowed 'personas decentes'/'decent people' to enter the grounds (Simón Palmer 2001: 70). King Carlos III, it is said, opened the gardens of the Retiro to the public with the restriction that they dress appropriately (Montoliú Camps 2002: 672). This explicit condition revealed that the invitation was extended only to those who dressed for the occasion, i.e. those who adopted for the duration of the visit those norms of social conduct, or who embodied those socially normative constructs, privileged by the King. In 1867 the people of Madrid were allowed access to the Estanque (Simón Palmer 2001: 98), and under the First Republic, new paths were opened and the gardens were transformed (Simón Palmer 2001: 101). What this example brings to light is that, during the late nineteenth century just as the early twenty-first century, under the rulings of royalty or republic, at the behest of government or capital, access to city-spaces has been defined by powerful material and immaterial processes. Action thus faces the daunting task, one not particularly recognized by common perception, of using the material space of the city to combat the less material mental structures and divisions which obtain in the spatialization of the city itself. Moreover, the spatialized conceptual tools of 'public' and 'private' conjoin with the aims of city-design to restrict and define, to separate and limit, all in the name of capital accumulation. If scholarship is to better act as a complement for action, it must do so by calling attention to the insufficiency of apprehending spatial processes through static categories. Rather than struggle for the pipe 
dream of a truly public place, scholarship must relinquish the utopian ideal in favor of a deeper understanding of the fundamental role that power structures play in the perception, production, interpretation and reproduction of our common world.

\section{Conclusion}

In approaching the struggle over the Retiro Park, we must reject those solutions motivated by the utopian ideal of a public sphere in which the appearance of private interests is mystically short-circuited. Rather, Larra was right-all appearance is structured by what can be termed 'private' motivations. We must point out, then, how the mechanism of marginalization is made visible through spatial movement in the park, and struggle not only against the deployment of strategies of marginalization within the confines of the park itself but against the ideas that although visible here are still only potentially or virtually (à la Bergson) visible elsewhere. There is design flaw in the idea of public space-it can never explain how a given space, such as a park, comes to be free of the 'private' (personal and structural) interests operating through its societal context. ${ }^{26}$

I have argued that the produced distinction between public and private obscures our apprehension of unfolding social problems and that we might do better to relinquish its hold in order to work towards constructing socially just places. I have suggested that we question the terms of traditional cultural analysis in order to embrace a more relational and dynamic approach to the production of space. This is moreover to question the ontology of intellectual categories and see how when we purport to be discussing spatial practices we are merely extending into space the trick of the intellect to see static abstractions where there is fluid movement. This is to embrace a materialism that already acknowledges the immaterial, one that is determined to avoid the pitfalls of traditional realist and idealist reductionism and thus to acknowledge the material effects of the movements of cultural conceptual production (see also Harvey 1989, 1990, 1996, 2000; Latham and McCormack 2004; Lefebvre 1991 [1974]). As critics who embrace space as a process are aware, the production of space necessarily entails both mental as well as cartographic aspects. Furthermore, the unity of these two dimensions must be incorporated into any theoretical discourse that hopes to approach a real acknowledgement of, and a possible solution to, dynamic spatial problems. Material space is not merely a container for ideas; ideas do not form an ontologically distinct category from the physical any more than material realities can be understood apart from the immaterial concepts that structure their formation.

In action, the idea and the physical world are one and the same. If, in analyzing restricted access to the Retiro Park, we tread a well-worn path to ideas of 'public/private' space then we draw attention away from the brute force of the mental/material nature of power as produced in spatial practice. Entwined with these discourses are the people who practice them and who use/are used by them in the production of spaces-restricted spaces, protected spaces, spaces of marginalization, spaces of violence. As Franklin asserted, we must reject a production of space that valorizes safety over liberty. In the tradition of Larra we must realize that public space is itself exclusionary. As does Foucault we must recognize that liberty is a constant practice. Yet, moreover, we must question the 
mental categories that create the illusion of public space and seek to practice liberty in both thought and in action.

In struggles over city-space such as the Retiro Park, both activism and scholarship have roles to play. A scholarship that does not, in fact, challenge the reification of the various terms that the intellect is led to employ in its bending towards action will find itself increasingly removed from both thought and action. It will think itself, or it will think nothing at all. Although a scholarship that does challenge mental abstractions in the analysis of the production of space will in the short run find itself bereft of its conceptual tools, it will-at length-provide a place for a thought more complementarily engaged with action. Just as space is a process that is structured by divisions and partitions that serve certain interests, our thinking about space is likewise a movement that is structured by spatialized terminology such as the 'public/private' distinction. Activism must draw attention to the spatialization of the city. Scholarship must question the spatialization of the concepts through which we intellectualize space. Each needs the other to survive.

\section{Acknowledgements}

I am greatly indebted to both Malcolm Compitello and Sallie Marston.

\section{Notes}

1 The few scholarly articles that have touched on parks in Madrid include Ariza Muñoz, who delves into unrealized plans for a park in Madrid called the Campos Eliseos (1988) and then offers a historical and functional description of various constructions in Madrid's parks, some of them in the Retiro (1993); Remón Menéndez (1998) looks at the creation of the
Parque del Oeste as part of the late nineteenth-century expansion of Madrid and touches in passing on its problematic relation to the class struggle-'Parque del Oeste definitely seemed more to want to transform the working class into middle-class people than to satisfy the genuine needs of those working classes' (1998: 204); and Rodríguez Romero and Prieto González (1997) trace the development of nineteenth-century public recreation spaces with a focus on the Retiro.

2 I do not wish to engage culture as opposed to nature, as has been historically done (see Johnston, Gregory, Pratt and Watts, 2000; Williams 1977). Such an opposition is, of course, the basis of any approach that relegates the cultural to a mere symbolic mode of representation superimposed upon a material reality.

3 This idea is embedded in perhaps his most widely acknowledged metaphor-that of 'the cinematograph of the mind.' If we take instantaneous snapshots of the surrounding world, he says, this is merely to be able to insert our action into the unending movement of experience.

4 This is the tendency of Marston's statement recognizing the "“nexus" among' and 'mutually constitutive nature of the categories' of state, culture and space (2004: 38). This is the intention of Jessop's assertion that the boundaries between the economic and the political are of cultural origin (1999: 380). The uncritical engagement of the culture/state division (see Van Deusen 2004) is only one such way in which the abstractions reified by the human intellect capture scholarly attention and manage to obscure the real movement inherent to social practice.

5 And yet, his solution ('By establishing the boundary between the two realms so that a civilized relationship can be promoted, the threat of encroachment by private interests into the public realm and the threat of public intrusion into the private sphere are both minimized and carefully managed'; Madanipour 2003: 241) falls short of a radical questioning of these terms and the acknowledgement that they have formed out of a power relationship. It is not that between spaces and representations of spaces there is a slippage, but rather that the problems that have arisen in the produced space of the Retiro call attention to contestatory spatial productions at work. Most importantly, to imagine the problem of access to the Retiro in terms of public/private space is to accept uncritically the very terms from which capitalist enterprise profits and explains away structural inequalities. 
6 David Harvey follows suit and explicitly bases his own investigations on this model (1990: 218-219).

7 Mitchell is certainly aware of the complexity of spatial practices. As a splendid example I cite his Cultural Geography: A Critical Introduction (2000). Even so, these complexities are somewhat smoothed out in his work on parks as his otherwise solid critique of entwined cultural and material processes yields slightly to the understandable need for tangible results in the fight for social justice.

8 Though talk of rights cannot assure group inclusion, he argues, it can provide a structure that various actors can refer to in the struggle over space. The emphasis he places on rights is too great given that the use/interpretation of rights is in itself a problematic area of social practice. Once rights are 'won,' what is to insure their correct interpretation and application by the courts? By law enforcement? What will assure that people are aware of their rights? Needless to say the jump from rights to praxis is a long one. Mitchell, in fact, undermines his own emphasis on the importance of rights in securing through law a precedent for the creation of public space through action. He writes, 'that idea [of public space] has never been guaranteed. It has only been won through concerted struggle, and then, after the fact, guaranteed (to some extent) in law' (2003: 5). There seems to be in the parenthetical clarification '(to some extent)' an implicit recognition that his own emphasis on rights is inadequate. Moreover, his statement that " rights talk"-and even more the practical assertion of rights-remains a critical exercise if social justice is to be advanced rather than constricted' (2003: 6, emphasis added) recognizes the disparity extant between rights and their meaning, interpretation and implementation. Moreover, we must nevertheless question the idea of 'public' which informs this discussion of struggle.

9 One acknowledgement of this invisible dimension of struggle is to be found in Lloyd (1997). He notes that nationalist movement struggles have relegated movements not identical with them to spaces of contingency. This space is 'the mythopoeic space of arrested development and fixity vis-à-vis the forward movement of nationalism itself. It is, then, to the resources of this mythopoeic space that national culture is held to recur in its atavistic moments, while its historical modernity finds expression in the state form. The state is both the proper end of historical process and the eternal antagonist of contingency and myth' (1997: 178). These non-identical struggles can be struggles of class or gender, as he notes is the case of Ireland, or by extension any movement that contrasts with the hegemonic constructed normality of the nationalist movement. Lloyd sees the development of the nationalist movement as interacting with state-oriented tendencies 'before or after independence' (1997: 188) and since, in the tradition of Ernest Gellner (1983), Lloyd notes that the 'nation desires the state,' we have just such a model of how small-scale disciplining in the Foucauldian sense interacts with the large-scale state-idea-through a practice of discarding that which cannot be disciplined; a practice performed by disciplined individuals. Of great interest here is how this same idea gets articulated in M. Augé's (1995) Non-places: Introduction to an Anthropology of Supermodernity with consequences for the argument at hand. He writes: 'If a place can be defined as relational, historical and concerned with identity, then a space which cannot be defined as relational, or historical, or concerned with identity will be a nonplace. The hypothesis advanced here is that supermodernity produces non-places, meaning spaces which are not themselves anthropological places and which, unlike Baudelairean modernity, do not integrate the earlier places: instead these are listed, classified, promoted to the status of "places of memory", and assigned to a circumscribed and specific position ... Place and non-place are rather like opposed polarities: the first is never completely erased, the second never totally completed; they are like palimpsests on which the scrambled game of identity and relations is ceaselessly rewritten' (1995: 77-78, 79). Here, Augé's non-place takes on the semiological ordering function of Lloyd's nationalism. While the latter relegates other social movements to an atavistic past, the former performs the same operation on place, on history, on identity. Movement through space is thus the material component of a sign more often recognized as ideological. It is the iconic representation of a semiotically arbitrarily-motivated sign and sign-system. Controlling access to space, in the Retiro Park or anywhere, is always intimately connected with the phenomenon that Lloyd terms nationalism and that Augé terms non-place.

10 From Frantz Fanon's A Dying Colonialism, quoted in Said (2000: 101).

11 There are numerous studies that have looked at the privatization of the public in Spain including those that have examined public services (García Fernández 1997) 
and others that have focused on political economy (Clifton, Comín and Díaz Fuentes 2003; Lavdas 1996). One such study by Bartolomé Clavero argues that the bourgeois revolutions in Spain in the nineteenth century 'brought about a new social order based on the privatization of social relations' (Cruz 1996: 12). McNeill (2002) argues that the Napoleonic occupation of the early nineteenth century in Spain effected a shift from feudal property regimes to privatization of space. This discursive focus of researchers finds a place, too, in more action-oriented protest. Fernando Alvarez-Uría, professor of sociology at the Universidad Complutense in Madrid, titles a 2002 short essay ' $\mathrm{La}$ privatización es un robo [Privatization is robbery].' The organization Attac Madrid rallies against the privatization of public services and against the Acuerdo General sobre el Comercio de Servicios (AGCS) [General Agreement on Marketed Services] (Attac Madrid 2003). Students in Madrid turn out by the thousands to protest the privatization of the University (Gómez 2000). Piketes (2003) announces a protest against privatization and capitalist neoliberalism in Madrid. EcoPortal.net reports on protests against the privatization of the railroad (Ordóñez 2003). In 2001 the street-cleaning utility in the Retiro neighborhood, and in two others in Madrid, was privatized (Sanz 2001) causing a four-fold increase in the cost to residents.

12 As capital and consciousness become increasingly urbanized in the uneven geographical development of capitalism, the city becomes the playground of those trying to accelerate turnover time (Harvey 2000). This can only be accomplished through the production of space and long-term investments. Capitalists and local, state, and federal governments work together to create spaces of long-term investment that will make money, but that will do nothing to minimize the disparity between what the upper tier earns and what the underclass brings home.

13 Investment in consumption spectacles, the selling of images of places, competition over the definition of cultural and symbolic capital, the revival of vernacular traditions associated with places as a consumer attraction, all become inflated in inter-place competition. I note in passing, that most of postmodern production in, for example, the realms of architecture and urban design, is precisely about the selling of place as part and parcel of an ever-deepening commodity culture. The result is that places that seek to differentiate themselves as marketable entities end up creating a kind of serial replication of homogeneity
(Harvey 1996: 298, drawing on Christine Boyer 1988; emphasis added).

14 'Lugar predilecto de los reyes ya desde la época de Felipe II, fue Felipe IV el que impulsó su creación y en 1868 se convirtió en propiedad del municipio' (www.madridhoy.net/ciudad/parques.htm). From this point on, all translations in the text are my own. The original Spanish will be included in the endnotes.

15 See La ilustración insuficiente [The Insufficient Enlightenment] by E. Subirats (1981) for a description of the persevering feudal structures in Spain.

16 See Baker and Compitello (2003: 24-25) where they cite Objectives and Criteria of the Plan General.

17 See Compitello's essay (2003a).

18 'Los quioscos y locales que se instalaron sin respetar la estética del lugar serán reubicados de acuerdo con la idea original. En fotos antiguas conservadas en el Museo Farroviario se puede apreciar que la farmacia, la fiambrería y la bombonería, mantenían el mismo estilo de la estación.'

19 'Los madrileños no tienen conocimiento suficiente del patrimonio monumental del que disponen.'

20 '....por razones de seguridad y para evitar el gamberrismo.'

21 This researcher was overwhelmed by the police presence on two separate visits to the park, in the summers of 2001 and 2002. Uniformed police, patrol cars and paddy wagons were extremely visible and most concentrated near the park's central pond area, a draw for tourists and non-white immigrants alike.

22 'Policías a caballo, en coche, en moto. Decenas de agentes recorren cada día, durante horas, el parque de El Retiro a la caza del inmigrante.'

23 '...16 decomisos de pequeñas cantidades de droga, una navaja; un indocumentado; tres personas sancionadas por consumir algún tipo de estupefaciente en público y 56 intervenciones menores, que incluyen desde pasear suelto al perro hasta la pérdida de un niño o una multa de tráfico por circular el parque.'

24 'los inmigrantes que lleguen a España no serán personas con reconocimiento legal y derechos, sino «ilegales obligados a aceptar cualquier condición de trabajo, a ocultarse, a callar ante las injusticias».'

25 'For us, appearance-something that is being seen and heard by others as well as by ourselves-constitutes reality. Compared with the reality which comes from being seen and heard, even the greatest forces of intimate life- the passions of the heart, the thoughts of the mind, the delights of the senses-lead an uncertain, shadowy kind of existence unless and until they are transformed, deprivatized and deindividualized, as it were, into a shape to fit them for public appearance ... the presence 
of others who see what we see and hear what we hear assures us of the reality of the world and of ourselves' (Arendt 1958: 50).

26 Instead, this error is based upon the mistaken philosophical premise (see Bergson 1998 [1907]) that 'nothing' might come before 'something' rather than that nothing is the presence of something with an additional movement of thought that negates that very something. It is not that space is public before it is made private, that nothing predates something, but rather that strategies and purpose are indeed coterminous with space from the beginning, and it is only that a necessarily positioned analysis has not considered those of interest until now. It is likewise problematic, as I have argued above, to imagine that private interests can be transcended to produce a public space, an idea which begs the doubled-question of whose interests must be transcended (minority groups) and whose will remain uncontested (investors).

\section{References}

Alvarez-Uría, F. (2002) La privatización es un robo, $<$ www.arrakis.es/ trazeg/uria2.html $>$.

Arendt, H. (1958) The Human Condition. Chicago: University of Chicago Press.

Ariza Muñoz, C. (1988) Jardines de recreo en Madrid: los llamados Campos Eliseos, Goya 204: 343-351.

Ariza Muñoz, C. (1993) Construcciones de carácter científico, cultural, artístico y religioso en los jardines de Madrid, Goya 234: 339-346.

Attac Madrid (2003) Contra la privatización de los servicios público ¡No al AGCS!, <www.attacmadrid. org/d/3/030116102940.php > .

Augé, M. (1995) Non-places: Introduction to an Anthropology of Supermodernity. trans. Howe, J. New York: Verso.

Baker, E. and Compitello, M.A. (2003) Madrid de Fortunata a la M-40. Un siglo de cultura urbana. Madrid: Alianza Editorial.

Berezin, M. (1999) Political belonging: emotion, nation, and identity in fascist Italy, in Steinmetz, G. (ed.) State/Culture: State-formation After the Cultural Turn. Ithaca, NY and London: Cornell University Press, pp. 355-377.

Bergson, H. (1998 [1907]) Creative Evolution, trans. Mitchell, A. Mineola, NY: Dover Publications.

Berman, M. (1982) All That is Solid Melts into Air: The Experience of Modernity. New York: Simon \& Schuster.
Berman, M. (1986) Take it to the streets: conflict and community in public space, Dissent 33: 476-485.

Blasco, P. (2000) El PSOE critica los constantes anuncios del cierre del Parque del Retiro, El Mundo, 1 Feb.

Boyer, C. (1988) The return of aesthetics to city planning, Society 25(4): 49-56.

Brown, M. (1997) RePlacing Citizenship: AIDS Activism and Radical Democracy. New York: Guilford Press.

Brown, M. (1999) Reconceptualizing public and private in urban regime theory: governance in AIDS politics, International Journal of Urban \& Regional Research 23(1): 70-87.

Canovan, M. (1985) Politics as culture: Hannah Arendt and the public realm, History of Political Thought 6: 617-642.

Clifton, J., Comín, F. and Díaz Fuentes, D. (2003) Privatisation in the European Union: Public Enterprises and Integration. Dordrecht: Kluwer Academic Publishers.

Commisso, S. (2000) Empezó la obra de remodelación de la estación de trenes de Retiro, Clarín, 26 Oct.

Compitello, M. (2003a) Del plan al diseño: El día de la bestia de Alex de la Iglesia y la cultura de la acumulación flexible en el Madrid del postcambio, in Baker, E. and Compitello, M.A. (eds) Madrid de Fortunata a la M-40. Un siglo de cultura urbana. Madrid: Alianza Editorial, pp. 327-351.

Compitello, M. (2003b) Designing Madrid 1985-1997, Cities 20: 403-411.

Cruz, J. (1996) An ambivalent revolution: the public and the private in the construction of liberal Spain, Journal of Social History 30: 5-27.

de Certeau, M. (1984) The Practice of Everyday Life. Berkeley: University of California Press.

de Larra, M.J. (1975 [1832]) ¿Quién es el público y dónde se encuentra?, in Mariano José de Larra: artículos. Barcelona: Noguer, pp. 173-180.

Diken, B. (1998) Strangers, Ambivalence and Social Theory. Aldershot: Ashgate.

Esteban, R. (2001) Aprendiendo a restaurar los monumentos, El Mundo, 10 Jan.

Flusty, S. (1994) Building Paranoia: The Proliferation of Interdictory Space and the Erosion of Spatial Justice. West Hollywood, CA: Los Angeles Forum for Architecture and Urban Design.

Foucault, M. (1984) Space, knowledge, and power, in Rabinow, P. (ed.) The Foucault Reader. New York: Pantheon, pp. 239-56.

Franklin, B. (1759) Historical Review of Pennsylvania. London: R. Griffiths, Paternoster Row, p. 289. 
Fraser, B. (2006) The difference space makes: Bergsonian methodology and Madrid's cultural imaginary through literature, film and urban space, $\mathrm{PhD}$ dissertation, Department of Spanish and Portuguese, University of Arizona.

Fraser, N. (1989) Unruly Practices: Power, Discourse and Gender in Contemporary Social Theory. Minneapolis: University of Minnesota Press.

García Fernández, C. (1997) The privatization of public services in Spain, in Lorrain, D. and Stoker, G. (eds) The Privatization of Urban Services in Europe. London: Pinter, pp. 133-146.

Gea Ortigas, M.I. (2002) Historia de los distritos de Madrid. Distrito 3: Retiro. Madrid: La Librería.

Gellner, E. (1983) Nations and Nationalism. Ithaca, NY: Cornell University Press.

Giroux, H. (2001) Public Spaces, Private Lives: Beyond the Culture of Cynicism. Lanham, MD: Rowman \& Littlefield.

Gómez, J.J. (2003) 6.000 estudiantes se manifiestan en Madrid contra la privatización de la Universidad, $<$ www.ua.es/dossierprensa/2000/03/10/8.html> .

Habermas, J. (1989) The Structural Transformation of the Public Sphere: An Inquiry into a Category of Bourgeois Society. Cambridge, MA and Cambridge, UK: MIT Press and Polity Press.

Harvey, D. (1989) The Urban Experience. Baltimore, MD: Johns Hopkins University Press.

Harvey, D. (1990) The Condition of Postmodernity. Cambridge, MA and Oxford: Blackwell.

Harvey, D. (1996) Justice, Nature and the Geography of Difference. London: Blackwell.

Harvey, D. (2000) Spaces of Hope. Berkeley: California University Press.

Houlbrook, M. (2005) Queer London. Chicago: University of Chicago Press.

Jessop, B. (1999) Narrating the future of the national economy and the national state: remarks on remapping regulation and reinventing governance, in Steinmetz, G. (ed.) State/Culture: State-formation After the Cultural Turn. Ithaca, NY and London: Cornell University Press, pp. 378-405.

Latham, A. and McCormack, D. (2004) Moving cities: rethinking the materialities of urban geographies, Progress in Human Geography 28: 701-724.

Lavdas, K. (1996) The political economy of privatization in southern Europe, in Braddon, D. and Foster, D. (eds) Privatization: Social Science Themes and Perspectives. Aldershot: Dartsmouth, pp. 233-260.
Lefebvre, H. (1968) The right to the city, in Kofman, E. and Lebas, E. eds and trans. Writing on Cities. Oxford: Blackwell, pp. 68-181.

Lefebvre, H. (1973) The Survival of Capitalism. London: Allison \& Busby.

Lefebvre, H. (1991 [1974]) The Production of Space, trans. Nicholson-Smith, D. Oxford and Cambridge, MA: Blackwell.

Lloyd, D. (1997) Nationalisms against the state, in Lowe, L. and Lloyd, D. (eds) The Politics of Culture in the Shadow of Capital. Durham, NC: Duke University Press, pp. 172-197.

Lloyd, D. and Thomas, P. (1998) Culture and the State. New York and London: Routledge.

Logan, J. and Molotch, H. (1987) Urban Fortunes: The Political Economy of Place. Berkeley: University of California Press.

Lubiano, W. (1996) Like being mugged like a metaphor: multiculturalism and state narratives, in Gordon, A. and Newfield, C. (eds) Mapping Multiculturalism. Minneapolis: University of Minnesota Press, pp. 64-75.

Johnston, R.J., Gregory, D., Pratt, G. and Watts, M. (2000) The Dictionary of Human Geography (fourth edition). Oxford and Malden, MA: Blackwell Publishers.

Madanipour, A. (1996) Design of Urban Space: An Inquiry into a Socio-spatial Process. Chichester: Wiley.

Madanipour, A. (2001) Multiple meanings of space and the need for a dynamic perspective, in Madanipour, A., Hull, A. and Healey, P. (eds) The Governance of Place. Aldershot: Ashgate, pp. 154-168.

Madanipour, A. (2003) Public and Private Spaces of the City. London: Routledge.

Marston, S. (1990) Who are 'the people'? Gender, citizenship and the making of the American nation, Environment and Planning D: Society or Space 8: 449-458.

Marston, S. (2004) What's culture got to do with it?: a response to Jakobsen and Van Deusen, Political Geography 23: 35-39.

Marx, K. (1975) On the Jewish Question, in Marx, K. and Engels, F. Collected Works, vol. 3. New York: International Publishers, pp. 169-170.

McNeill, J. (2002) Tragedies of privatization: land, liberty, and environmental change in Spain and Italy, 18001910, in Richards, J.F. (ed.) Land, Property, and the Environment. Oakland, CA: ICS Press, pp. 222-234.

Mitchell, D. (2000) Cultural Geography: A Critical Introduction. Oxford: Blackwell. 
Mitchell, D. (2003) The Right to the City: Social Justice and the Fight for Public Space. New York: Guilford Press.

Montoliú Camps, P. (2002) Enciclopedia de Madrid. Barcelona: Editorial Planeta S.A.

Ordóñez, J.L. (2003) El desastre de la línea Madrid-Lleida se une al chapapote, <www.ecoportal.com.ar/articulos/ madrid-lleida.htm $>$.

Owen, C. (1992) Building a relationship between government and tourism, Tourism Management 13: 358-362.

Passerin d'Entreves, M. (1992) Hannah Arendt and the idea of citizenship, in Mouffe, C. (ed.) Dimensions of Radical Democracy; Pluralism, Citizenship, Community. London: Verso, pp. 145-168.

Philo, C. and Kearns, G. (1993) Culture, history, capital: a critical introduction to the selling of places, in Philo, C. and Kearns, G. (eds) Selling Places. The City as Cultural Capital Past and Present. Oxford: Pergamon, pp. 1-32.

Piketes (2003) Manifestación en Madrid el 2 de diciembre de 2001, <www.piketes.com.ar/internacionales/ madrid212.htm $>$.

Remón Menéndez, J.F. (1998) Nature and city: the Parque del Oeste and the expansion of nineteenth-century Madrid, Urban History 25: 189-210.

Rodríguez Romero, E.J. and Prieto González, J.M. (1997) Haciendo el jardín de las delicias. Ficción y realidad en relación a los ámbitos de recreo público decimonónicos, Archivo Español de Arte 70(280): 397-418.

Rosenzweig, R. (1983) Eight Hours for What We Will: Workers and Leisure in an Industrial City, 1870-1920. Cambridge: Cambridge University Press.

Rouhani, F. (2001) Transnationalization and state formation from below: the politics of media consumption in Tehran, $\mathrm{PhD}$ dissertation, Department of Geography, University of Arizona.

Said, E. (2000) In Macfie, A.L. (ed.) Orientalism. A Reader. New York: New York University Press.

Sanz, L.A. (2001) La limpieza en el barrio de Salamanca costará cuatro veces más que en Vallecas, El Mundo, 27 July.

Sauer, C. (1925) The morphology of landscape, University of California Publications in Geography 2: 19-54.

Simón Palmer, M.C. (2001) Jardines del Buen Retiro. Madrid: La Librería.

Staeheli, L. (1996) Publicity, privacy, and women's political action, Environment and Planning D: Society or Space 14: 601-619.

Subirats, E. (1981) La ilustración insuficiente. Madrid: Taurus.
Thorns, D. (2002) The Transformation of Cities: Urban Theory and Urban Life. Basingstoke: Palgrave.

Tristan, R.M. (1998a) SOS Racismo denuncia la presión policial a los inmigrantes en El Retiro, El Mundo, 15 Aug.

Tristan, R.M. (1998b) Escasos resultados del aumento de la presión policial en El Retiro, El Mundo, 29 Aug.

Van Deusen, R. (2004) The state, culture and rights: a response to Sallie Marston's 'Space, culture, state: uneven developments in political geography', Political Geography 23: 27-34.

Vidal Domínguez, M.J. (1988) Estudio de circulación urbana: el barrio del Retiro (Madrid). Estudios Geográficos 49: 421-443.

Wagner, R. (1981 [1975]) The Invention of Culture. Chicago: University of Chicago Press.

Williams, R. (1977) Marxism and Literature. New York: Oxford University Press.

Wilson, A. (1991) The Culture of Nature: From Disney to the Exxon Valdez. Oxford: Blackwell.

Wolf, E. (1999) Envisioning Power: Ideologies of Dominance and Crisis. Berkeley: University of California Press.

Young, I. (1990) Justice and the Politics of Difference. Princeton, NJ: Princeton University Press.

Zukin, S. (1991) Landscapes of Power: From Detroit to Disney World. Berkeley: University of California Press.

Zukin, S. (1995) The Cultures of Cities. Cambridge, MA: Blackwell.

\section{Abstract translations}

Le Parc Retiro de Madrid comme espace publiquement privé et les problèmes spatiaux de la théorie spatiale

Les travaux de recherche universitaire sur la production de l'espace requièrent une réévaluation en profondeur des catégories statiques utilisées pour l'analyse des processus spatiaux. En insistant sur l'espace en tant que processus, cet essai attire l'attention sur le Parc Retiro de Madrid et ce qu'il implique pour les processus d'accumulation du capital de grande ampleur. Il souligne en même temps l'insuffisance de la distinction séduisante mais problématique entre l'espace public et privé découlant des solutions faciles appliquées aux conflits sur l'espace urbain. Plusieurs critiques ont souligné d'ailleurs le point faible au niveau de la conception de l'idée de l'espace public. Celle-ci n'arrive jamais à fournir une explication de la façon 
dont un espace donné, tel un parc, peut exclure les intérêts "privés» (personnels et structurels) oeuvrant dans ce contexte de société. En fin de compte, l'histoire du Retiro met à l'avant plan le rôle pivot de l'espace urbain dans le processus de compétition capitaliste interurbaine, et laisse entendre que les notions idéalisées sur le rôle que les espaces vraiment "publics» jouerait au sein de la démocratie radicale et la citoyenneté ne se confrontent pas suffisamment à ce processus.

Mots-clefs: Madrid, Retiro, espace, privé, public, culture, production.

El Parque del Retiro, Madrid, como espacio públicamente privado y los problemas espaciales de la teoría espacial

La atención del campo académico en la producción de espacio exige un nuevo estudio detallado de las categorías estacionarias empleadas en el análisis de procesos espaciales. Destacando la importancia de espacio como un proceso, este trabajo tiene como enfoque la implicación del Parque del Retiro en Madrid en los procesos más ámplios de acumulación de capital. Al mismo tiempo, destaca las insuficiencias de la atractiva $y$, sin embargo, problemática distinción entre el espacio público y el privado, que obtiene soluciones fáciles a la lucha por espacio de ciudad. Como han indicado muchos críticos, hay un defecto en el diseño de la idea de espacio público-nunca puede explicar cómo un espacio dado, como un parque, llega a ser libre de los intereses (personales y estructurales) 'privados' que operan por todo su contexto social. La historia del Parque del Retiro subraya el papel central del espacio de ciudad en el impulso para competicióninterciudad capitalista, y sugiere que el segundo de estos procesos no se ha hecho frente a las nociones idealizadas del rol que los espacios verdaderamente públicos pueden tener en la democracia y la ciudadanía radicales.

Palabras claves: Madrid, Retiro, espacio, privado, público, cultura, producción. 
Copyright of Social \& Cultural Geography is the property of Routledge and its content may not be copied or emailed to multiple sites or posted to a listserv without the copyright holder's express written permission. However, users may print, download, or email articles for individual use. 